\section{HIV and the Law: Integrating Law, Policy, and Social Epidemiology}

Zita Lazzarini and Robert Klitzman

I $\mathrm{n}$ the foundational piece in this issue of the journal, "Integrating Law and Social Epidemiology," Burris, Kawachi, and Sarat present a model for understanding the relationship between law and health. ${ }^{1}$ This article uses the case of a specific health condition, the human immunodeficiency virus (HIV) infection, as an opportunity to flesh out this schema and to test how the model "fits" the world of the HIV pandemic. In applying the model to this communicable disease, we hope to illustrate the multitude of ways that laws affect the course of the pandemic as well as the course of an individual's vulnerability or resilience to the disease, and how the complexities of an individual's life dealing with the virus interface with the world of laws and legal institutions. Ultimately, we believe that in the case of HIV infection we will learn something about the nature of the connections between law and health.

We give a brief overview of the epidemiology of HIV infection that is particularly relevant from the perspective of the role of law. By epidemiology we mean both the more common analysis that focuses on geographic, risk behavior, age, gender, and temporal distribution of disease, including what we know of incidence and prevalence data, as well as social epidemiology, specifically the relationships between HIV infection and social determinants such as socioeconomic status, education, race, social cohesion, and social capital. This integrated framework sets the stage for the next step, seeking evidence of how law might act either as a pathway to disease or how it might structure the social determinants for disease that have been identified.

At its core, the HIV pandemic involves the deceptively simple act of the virus passing directly or indirectly from the body of one individual to the body of another. Laws, however, may affect many of the variables that determine when

Journal of Law, Medicine J Ethics, 30 (2002): 533-547. (C) 2002 by the American Society of Law, Medicine \& Ethics. and how transmission occurs; whether condoms are used, needles are shared, blood is tested; and even whether an infected person is likely to be on effective antiretroviral treatment that may reduce his or her risk of infecting others. At a deeper level, poverty, stigma, and discrimination are associated with increased vulnerability to HIV and a wide range of laws can exacerbate or mitigate each of these social conditions.

HIV is not transmitted through the air or through casual contact. Transmission requires some intimate connection, which, once identified, should be easy to prevent. Yet, interruption of transmission has proven difficult for many reasons. At times, law and policy may be ill suited to directly interrupting HIV transmission because they often fail to address the larger social context in which the behavior takes place.

This article will consider first how laws in the United States could plausibly act as pathways, or mechanisms, by which deeper social determinants affect health, specifically HIV risk and resilience. Next, it will address the role of law in shaping those determinants themselves. For each example, we will ask the following questions: (1) how do law and policy link with risk; (2) what evidence supports this link; (3) what conclusions can we draw from the relationship between law/policy and risk; and (4) based on these conclusions, what policy options or research questions can we identify that will enhance the use of law/policy as a structural intervention.

The article does not specifically address the role of law in HIV in the developing world, where the vast majority of the estimated 40 million people currently living with HIV reside. ${ }^{2}$

\section{EPIDEMIOLOGY OF HIV}

\section{Epidemiology}

Acquired immunodeficiency syndrome (AIDS) was first identified in 1981. Shortly after discovery of the first cases, 
epidemiologists from the Centers for Disease Control and Prevention (CDC) identified the major risk factors for AIDS and issued recommendations for the prevention of sexual, drug-related, and occupational transmission of the disease. ${ }^{3}$ The incidence of AIDS and deaths associated with AIDS increased in the United States during the 1980s, peaked in the early 1990s, and began declining in 1996 due to the effects of new antiretroviral therapies, treatments to prevent opportunistic infections, and decreases in the incidence of the HIV infection which leads to AIDS. ${ }^{4}$ As of December $2000,774,467$ persons had been reported with AIDS in the United States, and of these 448,060 are known to have died. ${ }^{5}$

In the United States, AIDS primarily affects men who have sex with men and racial/ethnic minorities; minority men who have sex with men are the most affected. Although men who have sex with men make up the largest group of persons affected by HIV and AIDS, rates have increased dramatically among women and minorities since the start of the epidemic. Reported AIDS cases among women increased from approximately 8 percent of all cases in 1981 to 23 percent in $2000 .{ }^{6}$ During the same time period, the proportion of reported AIDS cases among African-Americans increased from 25 percent to 45 percent of all cases, and among Hispanics from 14 percent to 20 percent of all cases.? Rates among white, non-Hispanic Americans decreased from 60 percent to 34 percent of all cases by $2000 .{ }^{8}$

In the period from 1988 to 1999 , rates of death from AIDS were consistently associated with poverty; the lower the income for a county, the higher the rate of death. ${ }^{9}$ In addition, death was associated with race; in 1999, rates of death among African-Americans were nearly 11 times higher than among whites. ${ }^{10}$ Although death rates from AIDS began to decrease after 1996, this decrease was disproportionately smaller among minorities, women, and residents of poorer areas of the country. African-American women and women from southern U.S. states showed the smallest decreases in rates of death. ${ }^{11}$

AIDS diagnoses also decreased starting in 1993, but the rate of decrease was smallest among minorities and residents of poorer geographic areas. ${ }^{12}$ Since 1995, AIDS diagnoses have been highest among African-Americans, who now represent almost half of all new cases. In 1999, diagnoses among the poor accounted for more than 40 percent of new cases. ${ }^{13}$

HIV incidence reached approximately 150,000 per year by the mid-1980s, then declined and remained level at an estimated 40,000 per year starting in $1992 .{ }^{14}$ Approximately 900,000 Americans are now living with HIV infection. ${ }^{15}$ Rates of new infections are highest among men who have sex with men and injection drug users (IDUs), and among AfricanAmericans compared with other racial/ethnic groups. ${ }^{16}$

Since the start of the epidemic in the United States, HIV transmission has been primarily associated with behavior high-risk sexual behaviors, including male-to-male and unprotected sex, and injection drug use. Increasingly, HIV and
AIDS are linked to social and economic disadvantage minority status, being female, and low income. ${ }^{17}$

\section{Social epidemiology}

The patterns of disease in a society reflect its social conditions. As stated in Burris, Kawachi, and Sarat (in this issue), social epidemiology searches for "societal characteristics that promote (or inhibit) health."18 The epidemiology of AIDS in the United States and globally gives substance to this association. Perhaps more than many other diseases, HIV is a "biologic expression of inextricably connected social experience." 19 HIV compels public health experts to examine broad social determinants of health as well as more proximal structural factors associated with health. ${ }^{20}$

HIV is linked with the behaviors of high-risk sex and injection drug use, and associated with societal conditions. The work of social epidemiologists illustrates the social and structural correlates and determinants of HIV. Social determinants include poverty, race, and gender, and are expressed as under- or unemployment, homelessness, poor education, racism, discrimination, gender inequality, and stigmatization. Structural factors that facilitate or inhibit infection with HIV, and progression from HIV to AIDS, may be expressed through access to economic resources, policy supports, societal attitudes, and organizational structures and functions; they may be implemented by governments, businesses, faith communities, justice systems, the media, educational systems, and other sectors that form or implement policies or procedures. ${ }^{21}$

Measures of disease and risk of disease by "race" appear in both epidemiology and social epidemiology, but with differing emphases. For social epidemiologists, "race" has complex meanings, since it describes a system of distinctions often relying on ideology, privilege, and politics for its continued justification. ${ }^{22}$ Overall, "race" is considered a social construct often based on superficial physical characteristics or common heritage, but poorly supported by biologic and medical distinctions. Social epidemiological research appears to show that there is something about "race" that affects health status and risk entirely independent of the identifiable physical differences - perhaps it is best explained as the effects of "racism." Here, when we measure diseases by "race," we may actually be measuring the effects of "racism" or the negative physical consequences of discrimination and stigma over a lifetime. ${ }^{23}$

Social epidemiology aims to describe these broad social determinants and more proximal structural factors that influence HIV/AIDS: how they relate to the disease, and the mechanisms by which they impact the disease. The basic premise of this paper is that law both acts as a pathway for social determinants that impact HIV and helps to establish or change those social determinants themselves. Ultimately, we ask if and how laws and policy may facilitate or prevent HIV infection and AIDS among individuals. 


\section{How Does Law Act as a Pathway from Social DETERMINANTS OF HEALTH TO HIV/AIDS?}

One way to conceptualize the relationship between laws and HIV is to describe how social determinants act through the pathway or mechanism of law to influence HIV risk or resilience in individuals and populations. This section briefly describes a variety of ways that law might be a pathway, and then discusses a few examples at more length.

There is limited research on the mechanisms through which law impacts HIV/AIDS. Most prevention research has focused on the impact of interventions on individual behavior rather than on the role of law or policy in those interventions. However, we can identify a few areas in which research has revealed some insights into the way law works and possible ways to use law to reduce HIV risk and facilitate care and treatment for those already infected.

First, we can deduce the mechanisms through which laws affect behaviors by observing existing laws. Laws may establish programs that make health care or public health services available (e.g., HIV-testing sites); create duties for health-care providers (e.g., mandated reporting of patients with AIDS); direct health officials to use information to target services or interventions (e.g., partner notification); punish prohibited acts (e.g., criminal HIV exposure/transmission laws); interpret community norms (e.g., anti-sodomy laws); establish criteria for health education (e.g., specifying HIVeducation activities); or control access to means of prevention (e.g., syringe exchange or over-the-counter sale laws). Laws appear to function by prohibiting and punishing acts (deterrence), allocating (or denying) services, shaping community standards and norms, signifying social acceptance (or disapproval), incapacitating wrongdoers, and providing benefits, among others. ${ }^{24}$

These mechanisms may operate proximally, as where law either does or does not require that blood products be tested for HIV and other pathogens; at an intermediate level, where law increases or decreases poor people's access to safe and stable housing; or more distally, by influencing social determinants, which in turn increase or decrease vulnerability to HIV.

\section{Access to treatment}

Since the United States has no system to guarantee universal access to health care, ability to pay for care or entitlement to insurance through employment or other status is a necessity. For those with the fewest financial resources, the poor, uninsured, and underinsured, a complex web of laws governing eligibility to various public programs acts as one mechanism mediating the effects of low socioeconomic status on their health.

Comprehensive access to high quality care is vital for the individual well-being of persons with HIV disease. The current recommendations for HIV care involve careful moni- toring of immune status, prophylactic treatment to prevent opportunistic infections, and combination antiretroviral therapy to delay or prevent progression of HIV disease to AIDS. ${ }^{25}$ Persons with HIV who are poor, uninsured, or dependent on government insurance (Medicaid) may be less likely to receive antiretroviral treatment than those with private insurance. ${ }^{26}$ Some studies have shown that access to treatment and health outcomes also vary by race and gender. ${ }^{27}$ In some states, persons with HIV have to wait until they are eligible for treatment through state AIDS drug assistance programs (ADAPs). Delays may mean that damage to their immune systems has already occurred..$^{28}$ Delays in care and treatment may mean that untreated persons will develop high viral loads and will be more likely to transmit the virus to others. ${ }^{29}$ Those who develop opportunistic infections, such as tuberculosis, pose a risk to others with HIV, to their friends and families, and to the public as a whole. ${ }^{30}$ In the simplest sense, law, in the form of budgetary allocations and specific rules on eligibility for Medicaid and state ADAPs, may act as a pathway through which poverty can lead to restricted access to care for HIV disease. Although these programs serve the vital purpose of providing some funding for care, their limitations ensure that not all needy patients get the full range of HIV services. Because minorities with HIV depend disproportionately on Medicaid and state ADAPs, law may also act as a pathway through which race ${ }^{31}$ can lead to poorer health care for HIV.

Law may also act as a pathway when it fails, as when the legal system does not provide remedies or promote equity. In this context, commentators have noted that very limited and ineffective legal remedies are available for claims of unfairness against Medicaid programs (e.g., claims for discrimination due to race or denial of services that match those of non-state insurance). ${ }^{32}$ In a larger sense, having 40.4 million Americans uninsured ${ }^{33}$ also represents a pathway through which the failure of law negatively affects health, including the health of those with HIV.

\section{Methadone treatment}

Law can also act as a barrier to or a facilitator of public health measures. The presence or absence of laws restricting access to sterile syringes, laws permitting syringe exchange programs, and federal regulations on the prescription and use of methadone illustrate this point. Other articles in this issue $^{34}$ discuss the laws related to syringe availability at some length. Here we turn to methadone availability.

An obvious means to reduce IDU's' likelihood of contracting HIV is to stop or reduce their frequency of injection. Opiate substitutes, including methadone, have been found to be effective in reducing injections and other HIV-risk behaviors, ${ }^{35}$ and to allow many IDUs to stabilize their lives in other ways. In the United States, while use of methadone for treatment of addiction is legal, its use for this purpose is 
limited to federally licensed clinics and subject to strict prescription limitations. ${ }^{36}$ Strict regulation has resulted in a "treatment gap" of up to 600,000 persons who are addicted to opiates but not in treatment. ${ }^{37}$

While restrictive regulation may help decrease abuse of methadone, limitations also exacerbate the overall shortage of drug treatment opportunities for many IDUs and contribute to stigmatization of IDUs as clients of methadone clinics. ${ }^{38}$ In this way, the law acts as a pathway for stigma, which in turn limits the number of IDUs willing to use methadone clinics and may negatively affect IDUs' attitudes toward themselves. Easing restrictions on methadone prescription and treatment could provide wider access to methadone maintenance and decrease related stigma. ${ }^{39} \mathrm{~A}$ consensus statement of a National Institutes of Health panel in 1997 recommended both loosening restrictions on the use of methadone and requiring coverage of methadone maintenance for all public and private insurance programs. ${ }^{40}$ Such modification could "mainstream" methadone treatment, making it both more accessible and acceptable.

\section{Drug control laws}

Ideally, criminal law and law enforcement are tools through which society ensures public safety and health and strengthens communities by reinforcing norms of noncriminal behavior. Unfortunately, criminal law and law enforcement can act as pathways for determinants that negatively impact health. Police use of racial profiling illustrates one way in which law enforcement practices related to criminal laws act as a pathway for racism to play out in the daily experience of many African-Americans and other minorities. ${ }^{41}$ How might such racial bias in the application of criminal laws impact HIV and HIV risk? We know that HIV and AIDS increasingly concentrate in minority communities, particularly African-American communities. (See "Epidemiology of HIV," above.) Consequently, the possible role of law, and particularly criminal law, in increasing (or decreasing) exposure to HIV for African-Americans and other minorities carries some epidemiological urgency. The design and enforcement of drug control laws in the United States is one possible means through which race and racial bias can influence health outcomes, here leading to increased HIV risk.

The evidence that U.S. drug control laws act as a mechanism for reinforcing the unequal experience of race and racism in the United States is substantial. In the last two decades, the implementation and enforcement of U.S. drug control laws has led to increased arrests and incarcerations for drugrelated offenses. ${ }^{42}$ The United States incarcerates its population at a rate (greater than $600 / 100,000$ population) that is second only to Russia (690/100,000 population) worldwide. ${ }^{43}$ Most European countries have rates at or below 100/ 100,000 population. ${ }^{44}$ The majority ( 80 percent) of growth in the U.S. federal prison population between 1985-1995 was due to drug convictions..$^{45}$ The number of women incarcerated for drug offenses grew by an astonishing 888 percent during this time, while those women incarcerated for nondrug offenses increased 129 percent. ${ }^{46}$ These statistics demonstrate a clear national trend toward strict, incarceration-focused drug laws. When these rates are disaggregated by race and sex, however, the disparate impact emerges. In 2000, white women in the United States were incarcerated at a rate of 63/ 100,000 , white men at $683 / 100,000$, Hispanic women at $117 / 100,000$, Hispanic men at 1,715/100,00, African-American women at 380/100,000, and African-American men at $4,777 / 100,000 .{ }^{47}$

The National Household Survey on Drug Abuse in 2000 estimated that 24.5 million Americans have used illicit drugs. Of these, 18.2 million (74 percent) were white, 2.7 million (11 percent) were African-American, and 2.4 million (10 percent) were Hispanic. ${ }^{48}$ In other words, Americans use illegal drugs in about equal proportions to their representation in the population. Rates of arrest, conviction, and incarceration for racial minorities, however, remain significantly higher than the rates for whites. African-Americans make up 38 percent of those arrested for drug offenses and 59 percent of those convicted. ${ }^{49}$ African-Americans serve an average federal drug sentence that is 49 percent longer than that imposed on whites. ${ }^{50}$

Specific drug control laws that appear racially neutral may have a disproportionate impact on minorities due to differing patterns of drug use. For example, crack cocaine has been sold predominantly in inner cities and marketed on the streets in minority neighborhoods. Mandatory sentencing guidelines impose disproportionately harsher penalties for crack versus powder cocaine, including mandatory minimum sentences for simple possession of crack, even by first-time offenders. ${ }^{51}$ Although approximately twothirds of crack users are white or Hispanic, in 1994, 84.5 percent of those convicted of possession of crack were African-American. ${ }^{52}$

As drug control laws are currently enforced, their health impact, particularly in terms of HIV risk, is particularly problematic. To the degree that arrest or incarceration results in drug users stopping drug use or entering treatment, they could have health benefits. However, drug treatment slots in prison are inadequate to the need, and drug use often continues in prison. Incarceration exposes inmates to risky sex and drug use, since condoms and clean needles are largely unavailable in prison and sex may be coerced. ${ }^{53}$ Additionally, disruption of social networks among drug users, sex workers, and other marginalized groups can change mixing patterns for drug use and sex work, exposing more individuals to infected partners and making it more likely that drug use or sex will occur in the most high-risk settings. Disruption of networks also decreases social supports. Each of these represent ways that frequent arrests and/or prosecutions can increase HIV risk in those communities. ${ }^{54}$ 
Laws designed to prevent commercial sex work or illicit drug use may also disproportionately affect the homeless. Homelessness, like race, makes an individual more likely to be arrested under certain kinds of laws, and exposes the homeless to incarceration much more frequently than the general population. For drug- and sex-related crimes, this is at least partly because homeless persons may trade sex for money or a place to sleep or use abandoned buildings or street settings to use illegal drugs. Some local ordinances, referred to as antihomeless laws, ban camping, loitering, or panhandling, all or some of which are typically done by the homeless..$^{55}$ Many behaviors related to homelessness put people at greater risk of HIV, including elevated rates of substance abuse and mental illness, multiple sexual partners, trading sex for money or shelter, and unsafe injection practices. ${ }^{56}$ Unfortunately, some of the laws intended to address homelessness or to prevent illegal drug use, sex work, or petty crime work only to increase the risks of the homeless. ${ }^{57}$ (See "Housing," below.)

Of course drug control laws were intended to protect the public health and welfare by decreasing dangerous activities - the use of illegal drugs and the criminal activity that often accompanies it. Some proponents of strict drug control laws, those which emphasize incarceration of offenders, have claimed they will primarily benefit African-American communities. ${ }^{58}$ To the degree that a policy of strict enforcement of drug laws and incarceration of offenders actually decreases drug use and related crime, and supports social organization of communities, such a policy might actually benefit minorities. ${ }^{59}$

From a theoretical perspective, there are at least three possible mechanisms through which these laws could work to shape individuals' behavior: deterrence, norm setting, and incapacitation. Deterrence, or an instrumentalist-based approach, suggests that individuals respond to laws based on their rational consideration of the penalties or the incentives in place to comply with the law. ${ }^{60}$ Another approach holds that individuals respond less to the instrumental effects of laws than to their normative effects. In other words, we are more likely to obey specific laws when they comport with what we think is right, fair, or moral. ${ }^{61}$ According to this model, our beliefs in the fairness and legitimacy of the legal system, the norms of our neighbors, how we fit into society, and how society treats us become very important. Finally, criminal law can work by incapacitating those who have violated the law (through incarceration) and thus prevent or delay subsequent violations.

Some commentators, however, worry that incarceration is unlikely to decrease drug use or make communities notably safer. They note that incarceration can only incapacitate a small proportion of active users. ${ }^{62}$ Consequently, the possibility that tough sentences will deter individuals remains low, since the risk of arrest for any single incident of law breaking is so small. ${ }^{63}$ Moreover, the racially disproportionate en- forcement might actually increase community distrust of law enforcement and undermine community members' attitudes toward the legitimacy of law. Since studies suggest that people are less likely to obey laws they feel are unfairly applied or lack legitimacy, ${ }^{64}$ the net effect of a policy of strict enforcement and incarceration may be to make fewer people likely to obey drug control laws..$^{65}$

\section{Criminal HIV exposure/transmission laws}

In recent years, state legislatures have devoted substantial effort to drafting and adopting HIV-specific exposure/transmission criminal provisions. ${ }^{66}$ Twenty-seven states currently have some provision criminalizing HIV exposure or transmission, and many states have more than one provision. ${ }^{67}$ Although these provisions have generated extensive commentary, ${ }^{68}$ whether and how these laws actually influence behavior has not been rigorously studied.

Currently, research is underway to test a model for measuring how laws influence individual decisions to engage in risky behavior. ${ }^{69}$ However, for this article the key question is whether these laws act as pathways for one or more social determinants or shape those determinants in some way. For example, do they contribute to stigmatization of persons with HIV or reinforce racist stereotypes? If either of these were true, the laws might have unintended health consequences, such as deterring those at risk from being tested and contributing to individual and social vulnerability in other ways.

Although we know that a substantial minority of the general public holds at least some stigmatizing attitudes toward people with HIV or AIDS, ${ }^{70}$ we know little about the actual impact of HIV-specific exposure/transmission laws on AIDS-related stigma. We might theorize that by criminalizing otherwise legal acts (consensual sex) by a person with HIV, such laws could cast all persons with HIV as criminals in the eyes of the general public. Or, from the perspective of the person with HIV, criminalizing a normal and pleasurable part of life could alienate that individual from the rest of society. In either case, fear of being stigmatized has been associated with individual reluctance to acknowledge risk and to seek testing or other preventive and care-related services. ${ }^{71}$

Another issue is whether these laws are actually a mechanism for racism. As we can see from the example of drug control laws, equally important to what the law says is how vigorously it is implemented and enforced. Overall, enforcement of criminal penalties for HIV exposure appears rare. One study found only 316 distinct prosecutions over 15 years of the epidemic (1986-2001)..$^{72}$ Although the investigators were not able to determine the race of all the defendants, the most notorious case in terms of media coverage involved an African-American man suspected of exposing more than forty white women and infecting thirteen of them. ${ }^{73}$ The media coverage of the case revealed many deep-seated stereotypes 
related to race and sexuality. ${ }^{74}$ Arguably then, either the law or the public attention surrounding its enforcement served as a mechanism for racism. But does this response increase or decrease HIV risk in either the African-American or white communities? Although incapacitation of individuals who continue to expose others to HIV could have a positive impact by reducing the overall risk of individuals being exposed, such risk reduction may have a high price. If enforcement of HIV-specific criminal laws magnifies or legitimizes expression of underlying racial fears, they could contribute to the larger adverse impact of race in our society.

\section{How Does Law Shape Social Determinants of Heatth?}

Fundamental determinants of health are distinct from specific causes of disease. This helps explain some failures of specific interventions to improve overall health status. Among groups with negative determinants of health, such as poverty, specific interventions to prevent or treat one disease may succeed, but other diseases associated with poverty might remain stable or increase. Thus, it would be erroneous to think that public health could define the perfect set of interventions to prevent HIV/AIDS without addressing fundamental determinants, and also wrong to think that interventions aimed at fundamental determinants would have an impact on only one disease. Recognizing the fundamental role of social determinants means that some interventions likely to reduce HIV risk will not necessarily appear HIV-specific. Consequently, this section shifts the focus of analysis to consider how law(s) might actually shape or restructure the environment, particularly broad social determinants of health, which in turn are important factors in HIV risk and resilience.

Social epidemiology demonstrates that in the United States elevated risk of HIV infection is associated with poverty and minority race/ethnicity. More rapid progression to AIDS and elevated AIDS death rates are associated with lower socioeconomic status, minority race/ethnicity, and female gender. $^{75}$ (See "Epidemiology" and "Social Epidemiology," above). We will examine the ways, known or proposed, that law and policy shape resources closely linked to social determinants housing and education - as well as several determinants: income inequality, race/racism, and social cohesion/human capital.

\section{Housing}

Housing could perhaps more accurately be called a resource, or an "intermediate factor," than a fundamental determinant of health. Housing, however, is closely linked to socioeconomic status, social cohesion, and other more fundamental determinants. It is also both clearly linked to HIV risk (and adherence to treatment) and shaped by law.

Even laws meant to provide housing can actually perpetuate instability, poor living conditions, and homelessness. Laws, regulations, and policies influence who, among the homeless or unstably housed, is eligible for housing. For example, the Department of Housing and Urban Development (HUD) defines a homeless person in very specific terms, and some programs exclude persons who are in substandard or crowded housing or living with friends or relatives. ${ }^{76}$ State and federal governments provide a variety of programs to help persons who lack shelter, but in some cases individuals may be ineligible for housing supports because of behavioral problems such as drug use or criminal records. ${ }^{77}$ Those who have recently arrived in a city may be excluded from local housing and social services because they do not meet residency requirements or because they lack necessary knowledge of local procedures for accessing services. This problem will be even greater for homeless persons, who lack neighborhood networks and sources of local information, and who must attend to housing needs before seeking other services. When these new arrivals are HIV-infected, they may delay accessing prevention and treatment services. ${ }^{78}$

Availability of housing influences risk of or resilience to HIV infection. This is partly because lack of housing covaries with poverty and with related behaviors such as trading sex for money and drug use. ${ }^{79}$ Housing also offers hygiene, safety, and shelter; it supports the maintenance of nurturing relationships; and because it provides a stable mailing address, it enables access to various health and social services that help to maintain or improve health behaviors and health status. The homeless, like those infected with HIV, are often stigmatized as unproductive members of society, dangerous or unpredictable, and culpable for their situation. ${ }^{80}$ By contrast, having housing confers some status and affirms membership in society.

Housing has a particular impact on risky behaviors leading to HIV infection, and on the status and care of persons who are infected with HIV or who have AIDS. Studies have found high rates of HIV infection and high rates of HIV risk behaviors among homeless youth, ${ }^{81}$ among adults who are homeless, ${ }^{82}$ and among those who are homeless and substance users and/or mentally ill. ${ }^{83}$ In addition, research has documented that for persons with HIV, those with housing are significantly more likely to access appropriate health care and to adhere to medications than those without housing. ${ }^{84}$

\section{Poverty and income inequality}

On a global scale, the United States is far from being a poor country. ${ }^{85}$ The benefits of our national wealth are far from equally distributed, however. Income inequality in the United States is markedly greater than in many other developed countries $^{86}$ and is worse now than 30 years ago ${ }^{87}$ Research has documented that it is income inequality, not absolute level of income, which is most closely associated with disparities in health. ${ }^{88}$

How does law help create, maintain, or change the degrees of income inequality in the United States and thus the 
determinants of HIV? One way that law might influence or shape income inequality is through debtor-creditor law. These laws could increase income inequality by exacerbating the problems of debt, making it more difficult for consumers to get out of debt, and promoting loss of assets by persons who temporarily lose their income. Debtor-creditor-related law may actually predispose some households to adverse health effects. ${ }^{89}$ Studies demonstrate the relationship between low income and $\mathrm{HIV}^{90}$ An interesting question, unanswered by the current data, is whether debtor-creditor law has a direct effect on HIV-related risk behaviors or states (substance abuse, depression), or whether it acts more indirectly, by decreasing household income, increasing income inequality, and contributing to economic instability for those individuals and families in or near bankruptcy.

We can readily identify other types of laws that contribute to increasing income inequality. As discussed elsewhere in this issue, ${ }^{91}$ the current tax code and modifications in the last two decades have contributed to greater income disparities in the United States. To the degree that income inequality contributes to ill health, the tax code could be viewed as having potentially negative impacts on health and HIV risk in particular.

Welfare laws also shape poverty and income inequality, yet the nature of that relationship is complex. Until 1996, welfare in the United States was a federal entitlement program providing some level of guaranteed income support to a large number of persons who were unemployed. Public support for welfare eroded as critics argued that rather than helping recipients to get out of poverty, welfare actually perpetuated dependence and reinforced the gap between the gainfully employed and those on public assistance. ${ }^{92}$

In 1996, Congress eliminated the federal entitlement to welfare and replaced it with a mandated job training program to be implemented at the state level. State "welfare to work" programs imposed a 5-year lifetime cap on the length of time any individual could receive benefits. ${ }^{93}$ The goals of these reforms were to get the poor off welfare and into work, with the presumption that this would reduce poverty and dependence. In the first years of the new program, most states showed sharp declines in the number of persons receiving public benefits. ${ }^{94}$ These years coincided, however, with the longest peacetime expansion of the U.S. economy in the twentieth century. Overall unemployment levels reached all-time lows and the availability of entry-level jobs facilitated the transition to work for many former welfare recipients. Whether "welfare to work" programs will be as successful during economic downturns remains unknown. ${ }^{95}$ From the perspective of this article, the key question is whether such programs reduce income inequality, leave it largely untouched, or make it worse.

Previous antipoverty programs have been shown to have some positive benefits, though not directly related to health or HIV. Preschool programs, such as Head Start, that pre- pare poor preschoolers to enter kindergarten with the same skills as middle-class children, have been shown to increase readiness for school, enhance school performance in the early grades, and raise high school completion rates. ${ }^{96}$ Job training programs, such as the Comprehensive Employment and Training Act (CETA), led to marked improvements in the wages of the women who participated. Yet neither Head Start nor CETA has received sustained political support (CETA was discontinued in 1982) or funding adequate to enroll all those eligible at any one time. ${ }^{97}$

Unfortunately, law can also interfere with programs intended to help poor men and women maintain an adequate standard of living and satisfy their basic income and nutritional needs. One section of the 1996 welfare reform act passed by Congress bars anyone convicted of a state or federal felony involving the sale or use of drugs from ever receiving cash assistance or food stamps. ${ }^{98}$ Notably, convictions for violent crimes, including murder, do not carry the same ban on federal assistance. Currently, an estimated 92,000 women, many with children, in twenty-three states are covered by this ban. ${ }^{99}$ This deprives women of a key source of income support, which may help them keep stable housing, provide nutritious food for their families, and avoid illegal means to supplement their incomes. Additionally, the lifetime ban seems poorly related to the overall goals of the welfare or food stamps programs. ${ }^{100}$ To the degree that such policies increase or decrease income inequality, they may work on a much deeper level to affect the health of populations.

If we take seriously the epidemiologists' findings linking income inequality to health and to risk of specific diseases including HIV, laws that could affect income inequality and HIV risk or resilience are natural targets for potential policy change. If we know law shapes the determinant, and we know the determinant is associated with HIV risk, this information can provide us with guidance for identifying and promoting policy options.

\section{Race and racism}

How does the law structure race and racism in this country? Since the repeal of laws that discriminated explicitly on the basis of race, this question has been more difficult to answer.

The role of the law in supporting stigmatization and isolation of African-American men who have sex with men is subtle. Problems may have to do with a lack of laws or policies, or a failure to enforce them. For example, state health policies may fail to offer active and targeted prevention services to minority groups because limited resources are used for surveillance, testing, or contact tracing. School districts may not offer HIV-prevention education. ${ }^{101}$ Policies may endanger persons in minority neighborhoods by failing to address deterioration and urban decay. ${ }^{102} \mathrm{Health}$ officials may fail to enforce laws against revealing the names of in- 
fected persons during contact investigations, thus contributing to mistrust of service and prevention agencies among minorities. ${ }^{103}$

Discrimination against African-Americans by other racial groups, and stigmatization and isolation of African-American men who have sex with men, may lead to highly risky behaviors and to sexual and drug-use mixing patterns that put young men who have sex with men in contact with partners who are likely to be infected. ${ }^{104} \mathrm{~A}$ recent study of HIV infection among groups of young men who have sex with men who were tested between 1994 and 1996 in seven cities revealed 14 percent HIV prevalence among young African-Americans in this group, compared to 7 percent of Hispanics and 3 percent of whites. ${ }^{105}$ The incidence rate among African-Americans was 4 percent per year compared with 1.8 percent among Hispanics and 2.4 percent among whites. ${ }^{106}$

Earlier this paper examined drug control laws as a mechanism or pathway for racism with impacts on health. But here we consider how these and other laws shape race and racism itself. The highly disparate impact of the enforcement of drug laws on minorities, and African-Americans in particular, and their high rates of incarceration have created a widespread perception of an association among AfricanAmericans, drug use, criminal activity, and dangerousness. This stigmatization of all African-Americans has led Tracy Meares to label incarceration as a "race-making factor." By a "race-making factor" she means "a physical construct [similar to ghettos] that sustain[s] and nourish[es] an African-American identity that is in opposition to "mainstream' American identity." 107 Not only does this stigma reinforce false stereotypes among the non-African-American population in ways that perpetuate racist attitudes (and behavior, and potential health effects), but it can also have a more profound effect. This stigma may encourage AfricanAmericans who have neither been incarcerated nor used drugs to assume that "mainstream" American identity and values do not apply to them.

\section{Community social organization}

The concept of community social organization is a sociological theory of determinants of low crime rates; it bears a striking resemblance to social epidemiology's view of determinants of population levels of disease. The concept of community social organization maintains that it is the characteristics of the community, rather than its individual members, that predisposes the community to lower rates of crime, delinquency, and feelings of safety and security. ${ }^{108} \mathrm{Fac}-$ tors social epidemiologists consider important, including social capital, social cohesion, education, and socioeconomic status, fit well with this model. Thus, social determinants of disease may also support characteristics of a community that contribute to stability, safery, and lower levels of crime. Ulti- mately, strong community social organization, to the degree that it includes improved social determinants, ought to produce better health status, including lower levels of HIV infection and a more supportive environment for those already infected.

\section{Social capital and social cohesion}

Drug control laws and their enforcement negatively affect each of these determinants in a variety of ways. Because of the disenfranchisement provisions of many states' laws, approximately 13 percent of African-American men are currently unable to vote. ${ }^{109} \mathrm{By}$ some estimates, this proportion will grow to more than 30 percent in coming decades. Voting is a powerful measure of social participation and it is closely linked to other measures of social participation, including membership in civic groups and participation in community improvement activities. ${ }^{10}$ Depriving such a large portion of minority residents of a key element of civic involvement decreases the social capital of everyone in the community, limits the community's voice in municipal, state, and national elections, and discourages other communitybuilding activities. Additionally, the identity of "convict," which adheres to former prisoners, makes it difficult for them to invest in building individual social capital through education or gainful employment. Because former prisoners are not usually considered good candidates for educational opportunities, good jobs, or close relationships with other community members, they are also less able to contribute to the social capital of the community."11

High rates of incarceration also decrease social cohesion by disrupting social networks of families, friendships, and organized community life. For example, the Bureau of Justice Statistics indicates that 2.8 percent of all children under 18 have at least one parent incarcerated. This breaks down to 1 in 40 with an inmate father and 1 in 359 with an inmate mother. ${ }^{12}$ One study found that "Black children $(7.0$ percent) were nearly 9 times more likely to have a parent in prison than white children ( 0.8 percent). Hispanic children (2.6 percent) were 3 times as likely as white children to have an inmate parent." 113 Incarceration of parents deprives children and adolescents of adult supervision, and when many parents in a community are incarcerated, it can drastically decrease the number of adults available to supervise children. ${ }^{114}$ Adult supervision is one means of reducing risky behaviors by adolescents, such as smoking, alcohol and other drug use, vandalism, mischief, and petty crime.

\section{Education and socioeconomic status}

Incarceration is associated with a long-term decline in socioeconomic status for those who have been incarcerated. ${ }^{115}$ These reduced prospects may be due to several factors. Being identified as a former "convict" can directly limit job 
opportunities, ${ }^{116}$ since many employers will not hire someone with a criminal, especially felony, record. Conviction for a drug offense can also indirectly affect long-term earning prospects by decreasing educational opportunities, since educational level is closely associated with income and socioeconomic status. Federal law now bars students who have been convicted of a drug offense from receiving federal student loans. ${ }^{117}$ Given the disproportionate impact of drug law enforcement, this burden falls heavily on minority young people.

Families where the father or husband is absent are closely associated with poverty, ${ }^{118}$ so incarcerating one parent increases the likelihood that children will experience poverty. ${ }^{119}$ Single-parent families headed by young women are also less likely to be able to send children to college. Even where children of such families are accepted to college, there may be fewer parental or family resources to help them. By limiting the educational opportunities of the next generation, incarceration of parents for drug crimes perpetuates the problems of low socioeconomic status from generation to generation. ${ }^{120}$

Low socioeconomic status and lower levels of education are both associated with increased HIV/AIDS risk. ${ }^{121}$ Although not the sole factor, laws that perpetuate low socioeconomic status and limit education for those convicted of drug offenses and their children arguably shape important determinants of disease.

\section{Potential Structural INTERVENTIONS TO DECREASE HIV RISK}

Whether and how laws actually work to influence behavior, make environments safer, and facilitate public health are important questions to those interested in HIV prevention and control. Key aspects of our public health and clinical interventions are authorized, required, permitted, funded, or shaped by laws. Laws form the foundation of public health work; they articulate the mission, set the agenda, and establish policy priorities. ${ }^{122}$ In this section, we discuss future directions for the law as a structural intervention to reduce $\mathrm{HIV}$, and the limitations to this approach.

\section{Policy options}

Consideration of the impact of proposed laws on social determinants (such as income inequality) deserve a place in the routine analysis of public health and other policy initiatives. Much like the various "human rights impact assessments" that have been developed ${ }^{123}$ (see also the articles by Watchirs, and O'Keefe and Scott-Samuel, in this issue ${ }^{124}$ ), such an analysis could assist in the design of policies most likely to be effective against a certain disease or health condition, while giving preference to policies that are likely to benefit social determinants.

Strengthening some laws could have an immediate impact on HIV risk and resilience. Examples include expanding laws that provide methadone as an opiate replacement or improving access to comprehensive HIV care, such as through Medicaid. In fact, provisions that would increase access to HIV therapy have been estimated to produce net economic benefits through reduced hospital costs and improved retention of HIV-infected workers. ${ }^{125}$ Increased legal emphasis on prevention and treatment of drug use might help to reduce drug-related incarcerations and associated HIV risk. In addition, eliminating mandatory sentences and restoring discretion to judges in sentencing for all forms of drug offenses could reduce the negative effects of incarceration for many first-time or nonviolent offenders. Judges could reserve prison time for those offenders for whom prosecutors strongly support incapacitation.

Law might assist with much longer term approaches to HIV prevention by influencing underlying social determinants, such as the level of community social organization or access to important resources such as education and housing. For example, city planning that seeks to promote mixed housing with access to public transportation and employment for all economic classes and races might reverse some of the concentrating effects that urban, innercity communities are having on the HIV/AIDS epidemic. Changes in the drug control laws and law enforcement practices could help to decrease stigmatization of minorities as dangerous drug users, and reduce disruption of social networks, loss of social cohesion, and diminution of social capital that flows from labeling so many community members as "drug felons" or "convicts." Changes in laws that restrict the access of ex-prisoners to educational loans, public assistance, food stamps, or public housing would promote access to important resources that are closely linked to improving social determinants.

Efforts to change fundamental determinants might seem frustratingly slow and indirect in the face of a serious epidemic like HIV/AIDS. However, these interventions can be coupled with those that will have more immediate effects, especially where those effects are tailored to supporting social systems. Meares describes this approach to building community social organizations in communities with high levels of drug abuse and related crime. In contrast to some social scientists who discuss only interventions aimed at poverty and aspects of social organization, she emphasizes the importance of including law enforcement in any effort to decrease the harms of drug abuse. ${ }^{126}$ She writes that policing ought to promote a sense of safety among community members, encourage civic participation, and build trust among neighbors and between the community and law enforcement. ${ }^{127}$

\section{Possible limitations of law as a structural intervention}

Whether and how laws are implemented and enforced will have an impact on their ultimate efficacy. For example, some 
laws may seek to regulate behavior that is so private or so intimate that the law proves a poor tool for change. Commentators have noted that sodomy, adultery, and fornication have all been prohibited at times, but few claim the laws were effective in abating the behaviors. ${ }^{128}$ Other laws, including those criminalizing HIV exposure/transmission, are so rarely enforced that their practical importance may be questioned. ${ }^{129}$

Individuals and communities also understand laws differently, depending on their knowledge, familiarity with the legal system, and trust in governmental authority. Empirical studies reveal that many people harbor misperceptions about laws, including those related to HIV. ${ }^{130}$ Where laws are perceived as illegitimate, they may be less likely to shape behavior, norms, or a sense of engagement in the process of disease prevention and health promotion. ${ }^{131}$

\section{Policymaking}

Although both medicine and public health increasingly rely on "evidence-based" approaches, public health laws and policies are not subjected to similar scrutiny. This absence is apparent both in the occasional failures of policymakers to rely on sound science in making policy, and in the general dearth of literature empirically evaluating the impact of public health laws, regulations, or policies. Specific to HIV interventions, a national conference convened at the National Institutes of Health (NIH) in 1997 to look at interventions to prevent HIV risk behaviors concluded that "the gap between science and public policy is frightening." 132 This gap between science and policy may persist if legislators lack adequate access to scientific information or must consider competing policy priorities. However, the nature of the law and the legal system itself may also contribute to this gap. Scientists and lawyers often speak different languages. Public health officials, medical clinicians, and behavioral scientists speak in terms of "probability," "risk," and "associations" between behaviors and disease; whereas lawyers use terms such as "proof," "guilt," "innocence," "right," and "wrong." In fact, one commentator notes that, in addition to a general disregard for empirical research, the law and lawmakers exhibit a very low level of understanding of human behavior. The law is, he states, "every bit as sociologically impoverished as it is psychologically impoverished." 133

Where lawmakers are reluctant to use science and scientists rarely study the empirical effects of laws, our knowledge of the impact of laws on health is limited. This poses a serious problem. If we as a society impose burdens on health agencies to provide services, track cases, and provide interventions, and we demand that individuals change intimate and/or pleasurable behaviors and sometimes punish them if they fail to do so, then we ought to know that the law works to produce its desired outcomes and minimizes unintended negative consequences.

\section{Conciusion}

Although previous research has often described or analyzed areas of law related to HIV prevention and control, considering law's role as a pathway or shaper of social determinants is somewhat new. This article reviews evidence from the scientific and legal literature on the potential role of law in relation to social determinants and illustrates an approach to integrating law and social epidemiology. We also hope that it has identified specific areas of HIV law and policy ripe for additional research, reform, or intervention.

Existing research suggests that law affects HIV risk and resilience at many levels, in many situations, both directly and indirectly, and that it does so through a rich variety of mechanisms. Understanding these effects and their mechanisms in more detail will allow policymakers, if they choose to rely on the research, to shape policy in a more positive way. Much more research is needed to clarify both effects and mechanisms at all levels. Policymaking, because it happens in the political arena, will inevitably be influenced by nonscientific considerations. Providing sound research is probably only one part of the solution. Another facet may be to consider whether health policy can be made more responsive to scientific information.

HIV serves as a rich case study. Nationally and globally, $\mathrm{HIV}$ is concentrated among the marginalized who face prior stigma and discrimination and also bear a disproportionate burden of other diseases. HIV-related policy and law may act as sensitive indicators of both population vulnerability and society's responsiveness to public health needs precisely because HIV so heavily affects marginalized groups. To the degree that law and policy can alter the equation of vulnerability and of risk and resilience, they promise to be key public health interventions.

\section{ACKNOWLEDGMENTS}

Work on this article was supported in part by CDC Grant No. R62/CCR317863, "A Structural Analysis of the Role of Law and Human Rights in Preventing HIV," and by a grant from the American Foundation for AIDS Research, "Health, Law and Human Rights: Exploring the Connections." The opinions and information expressed in the article are those of the authors and not of the Centers for Disease Control and Prevention or of the American Foundation for AIDS Research. The authors would like to acknowledge Esther Sumartojo, Ph.D., for her work on the project and her significant contributions to the article. We would also like to acknowledge research assistance from Lorilyn Rosales, Jennifer McSweeney, Amy Hozer, and Jonathan von Kohorn. Thank you to Theo Ungewitter for her assistance in preparation of the manuscript.

\section{REFERENCES}

1. S. Burris, I. Kawachi, and A. Sarat, "Integrating Law and Social Epidemiology," Journal of Law, Medicine Ü Ethics, 30, no. 
4 (2002): 510-21.

2. Centers for Disease Control and Prevention, AIDS Epidemic Update - December 2001, UNAIDS, available at <http:// www.unaids.org/epidemic_update/report_dec01/index.html $>$.

3. Centers for Disease Control and Prevention, "HIV and AIDS - United States 1981-2000," Morbidity Mortality Weekly Reports, 50, no. 21 (2001): 430-34.

4. Centers for Disease Control and Prevention, "U.S. HIV and AIDS Cases Reported Through June 2001," HIVIAIDS Surveillance Report, 13, no. 1 (2001): 1-36.

5. Centers for Disease Control and Prevention, HIVIAIDS Surveillance Report, 12, no. 2 (2000): at 5.

6. Centers for Disease Control and Prevention, supra note 3 , at 431 (Table 1).

7. Id.

8. See Centers for Disease Control and Prevention, supra note 2 .

9. J.M. Karon et al., "HIV in the United States at the Turn of the Century: An Epidemic in Transition," American Journal of Public Health, 91 (2001): 1060-68.

10. Id.

11. Id.

12. Id.

13. 1 .

14. See Centers for Disease Control and Prevention, supra note 2 .

15. Centers for Disease Control and Prevention, "World AIDS Day - December 1, 2000," Morbidity Mortality Weekly Reports, 49, no. 47 (2000): 1061.

16. See Centers for Disease Control and Prevention, supra note 2 .

17. Id.

18. Burris, Kawachi, and Sarat, supra note 1, at 511.

19. S. Zierler and N. Krieger, "Reframing Women's Risk: Social Inequalities and HIV Infection," Annual Review of Public Health, 18 (1997): 401-36, at 425.

20. E. Sumartojo and M. Laga, eds., "Structural Factors in HIV Prevention," AIDS, 14, suppl. 1 (2000): S1-S72.

21. E. Sumartojo, "Structural Factors in HIV Prevention: Concepts, Examples, and Implications for Research," AIDS, 14, suppl. 1 (2000): S3-S10.

22. N. Krieger, "A Glossary for Social Epidemiology," Journal of Epidemiology and Community Health, 55 (2001): 693-700.

23. N. Krieger, "Discrimination and Health," in L. Berkman and I. Kawachi, eds., Social Epidemiology (New York: Oxford University Press, 2000): 36-75.

24. S. Burris, "Introduction: Merging Law, Human Rights, and Social Epidemiology," Journal of Law, Medicine \& Ethics, 30, no. 4 (2002): $498-509$.

25. United States Public Health Service, Guidelines for the Use of Antiretroviral Agents in HN-Infected Adults and Adolescents (February 4, 2002), available at <http://www.hivatis.org/guidelines/ adult/May23_02/AAMay23.pdf>; 2001 USPHS/IDSA Guidelines for the Prevention of Opportunistic Infections in Persons Infected with HIV (November 28, 2001), available at <http:// www.hivatis.org/guidelines/other/OIs/OIGNov27.pdf $>$.

26. J. Levi and J. Dates, "HIV: Challenging the Health Care Delivery System," American Joumal of Public Health, 90, no. 7 (2000): 1033-36.

27. B.D. Smedley, A.Y. Stith, and A.R. Nelson, eds., Unequal Treatment: Confronting Racial and Ethnic Disparities in Health Care (Washington D.C.: National Academy Press, 2002): at 5 (summarizes findings of studies showing unequal access by race to HIV care (African-Americans receive less and lower quality care than whites), and negative impact on survival rates); R.D. Moore et al., "Racial Differences in the Use of Drug Therapy for HIV Disease in an Urban Community," N. Engl. J. Med., 330, no. 11 (1994): 763-68; M.F. Shapiro et al., "Variations in the Care of HIV-Infected Adults in the United States: Results from the HIV Cost and Services Utilization Study," JAMA, 281 (1999): 2305 15 (negative impact on survival for African-Americans); C.L. Bennett et al., "Racial Differences in Care Among Hospitalized Patients with Pneumocystis Carinii Pneumonia in Chicago, New York, Los Angeles, Miami, and Raleigh-Durham," Archives of Internal Medicine, 155, no. 15 (1995): 1586-92; K.H. Anderson and J.M. Mitchell, "Differential Access in the Receipt of Antiretroviral Drugs for the Treatment of AIDS and Its Implications for Survival," Archives of Internal Medicine, 160, no. 20 (2000): 3114-20.

28. L. DeSimione, "Guaranteeing Treatment Access," GMHC Treat Issues, 13, no. 4 (April 1999): 10-11.

29. M.A. Pedraza et al., "Heterosexual Transmission of HIV1 Is Associated with High Plasma Viral Load Levels and a Positive Viral Isolation in the Infected Partner," Journal of Acquired Immune Deficiency Syndrome, 21, no. 2 (June 1, 1999): 120-25; H. Chakraborty et al., "Viral Burden in Genital Secretions Determines Male-to-Female Sexual Transmission of HIV-1: A Probabilistic Empiric Model," AIDS, 15, no. 5 (March 30, 2001): 621-27; M. Hisada et al., "Virus Load and Risk of Heterosexual Transmission of Human Immunodeficiency Virus and Hepatitis C Virus by Men with Hemophilia. The Multicenter Hemophilia Cohort Study," Journal of Infectious Disease, 181, no. 4 (April 2000): 1475-78.

30. Centers for Disease Control and Prevention, "Prevention and Treatment of Tuberculosis Among Patients Infected with Human Immunodeficiency Virus: Principles of Therapy and Revised Recommendations," Morbidity and Mortality Weekly Reports, 47, no. RR-20 (1998): 1-58.

31. Smedley, Stith, and Nelson, supra note 27 , at 5 , and other studies cited in note 27 above.

32. S.D. Watson, "Race, Ethnicity and Quality of Care: Inequalities and Incentives," American Journal of Law \& Medicine, 27 (2001): 203-24, at 217-20.

33. Coalition Forms to Reverse Rising Trend of Uninsured Americans, Out of Many, One; Seniors USA (February 9, 2002) (reporting estimates of at least 40.4 million uninsured as of January 31,2002 , with approximately 2 million having lost insurance during the preceding 13 months), at <http://senrs.com/coalition forms to reverse rising trend_of_uninsured_americans.htm $>$.

34. Burris, Kawachi, and Sarat, supra note 1; Kim M. Blankenship and S. Koester, "Criminal Law, Policing Policy, and HIV Risk in Female Street Sex Workers and Injection Drug Users,"Journal of Law, Medicine ó Ethics, 30, no. 4 (2002): 548-59.

35. R.L. Hubbard et al., "Treatment Outcome Prospective Study (TOPS): Client Characteristics and Behaviors Before, During and After Treatment," in F.M. Tims and J.P. Ludford, eds., Drug Abuse Treatment Evaluation Strategies Progress and Prospects (Rockville, Maryland: National Institute on Drug Abuse, 1984): at 60; Effective Medical Treatment of Opiate Addiction, NIH Consensus Statement, 15, no. 6 (November 17-19, 1997): $1-38$, at 4 (panel concluded that "methadone maintenance treatment is effective in reducing illicit opiate drug use, in reducing crime, and in enhancing social productivity, and in reducing the spread of viral diseases such as AIDS and hepatitis"); M. Farrell et al., "Effectiveness of Drug Dependence Treatment in Prevention of HIV Among IDUs," Abstract No. A888, 13th International Conference on Reduction of Drug Related Harm, Ljubljana, Slovenia, March 3-7, 2002 (summarizes meta-analyses of the efficacy of drug treatment programs, including methadone maintenance, in reducing HIV-risk behavior; overall finding that methadone 
maintenance has a significant benefit on risk behavior, although some data inconsistent); M.W. Tyndall et al., "The Impact of Initiating Methadone Maintenance Treatment on Patterns of Drug Use and Other Risk Behaviors in Vancouver, Canada," Abstract No. A186, 13th International Conference on Reduction of Drug Related Harm, Ljubljana, Slovenia, March 3-7, 2002 (reporting "marked reduction in non-fatal over-doses, sex trade work, and incarcerations with modest reduction in overall drug use"); E. Gottheil, R.C. Sterling, and S.P. Weinstein, "Diminished Illicit Drug Use as a Consequence of Long-Term Methadone Maintenance," Journal of Addictive Diseases, 12, no. 4 (1993): 45-57.

36. National Institute of Drug Abuse, Buprenorphine Update: Questions and Answers, at <http://165.112.78.61/Bupupdate. html $>$ (last updated January 30, 2001).

37. Id.

38. D.A. Feillan et al., "Methadone Maintenance in Primary Care: A Randomized Controlled Trial,"JAMA, 286 (2001): 172431, at 1724.

39. B.J. Rounsaville and T.R. Kosten, "Treatment of Opioid Dependence: Quality and Access,"JAMA, 283 (2000): 1337-39; M. Weinrich and M. Stuart, "Provision of Methadone Treatment in Primary Care Medical Practices: Review of the Scottish Experience and Implications for U.S. Policy," JAMA, 283 (2000): 1343-48.

40. Effective Medical Treatment of Opiate Addiction, supra note 35 , at 2 .

41. D.A. Harris, Driving While Black: Racial Profiling on Our Nation's Highways, American Civil Liberties Union Special Report (June 1999), available at <http://www.aclu.org/profiling/ report/>; American Civil Liberties Union, "Is Jim Crow Justice Alive and Well in America Today?," at <http://www.aclu.org/ profiling/> (last visited May 11, 2002).

42. U.S. Department of Justice, Bureau of Justice Statistics, Prisoners in 1996 (Washington D.C.: U.S. Department of Justice, 1997).

43. M. Mauer, Americans Behind Bars: U.S. and International Rates of Incarceration, 1995 (Washington, D.C.: The Sentencing Project, 1997).

44. E. Currie, Crime and Punishment in America (New York: Metropolitan Books, Henry Holt and Company, 1998): at 15.

45. U.S. Department of Justice, supra note 42.

46. M. Mauer, C. Potler, and R. Wolf, Gender and Justice: Women, Drugs, and Sentencing Policy (Washington, D.C.: The Sentencing Project, 1999).

47. A.J. Beck and J. Karberg, Bureau of Justice Statistics, Prison and Jail Inmates at Midyear 2000 (Washington D.C.: U.S. Department of Justice, March 2001): at 9.

48. Substance Abuse and Mental Health Services Administration, U.S. Department of Health and Human Services, Summary of Findings from the 2000 National Household Survey on Drug Abuse (Rockville, Maryland: SAMHSA, 2001): at 124 (Table E.4), 132 (Table F.2), and 144 (Table F.14), available at <http:// www.samhsa.gov/oas/NHSDA/2kNHSDA/lot.htm > .

49. "Race and the War on Drugs," Drug Policy Alliance, Online Library, Focal Point (March 2001), available at <http:// www.lindesmith.org/library/focal_race2.html > (last visited June 5,2002 ).

50. M.R. Durose and P.A. Langan, Bureau of Justice Statistics, State Court Sentencing of Convicted Felons, 1998 Statistical Tables (Washington, D.C.: U.S. Department of Justice, December 2001): at Table 2.5, available at <http://www.ojp.usdoj.gov/bjs/ abstract/scsc 98 st.htm >; B.S. Meierhoefer, The General Effect of Mandatory Minimum Prison Terms: A Longitudinal Study of Federal Sentences Imposed (Washington, D.C.: Federal Judicial Center, 1992): at 20.
51. "Crack Cocaine Sentencing Policy: Unjustified and Unreasonable," The Sentencing Project, available at <http:// www.sentencingproject.org/brief/pub1003.htm > (last visited June 5,2002 ) (The federal law mandates similar sentences for quantities of crack: powder cocaine of 1:100, and mandatory prison sentences for simple possession of crack, even for first-time offenders. This means that someone caught with five grams of crack will be sentenced to 5 years in prison, while possession of five grams of powder cocaine will probably receive probation.).

52. Id.

53. "U.S. Prisons Fail to Adopt Proven Prevention Measures, Experts Say," AIDS Policy Law, 12, no. 6 (April 4, 1997): 1, 9-10.

54. See Blankenship and Koester, supra note 34.

55. D. Lee et al., "HIV Risks in a Homeless Population," International Joumal of STD o AIDS, 11, no. 8 (2000): 509-15; L.M. Takahashi, "The Socio-Spatial Stigmatization of Homelessness and HIV/AIDS: Toward an Explanation of the NIMBY Syndrome," Social Science \& Medicine, 45, no. 6 (1997): 903-14.

56. D.A. Zanis et al., "HIV Risks Among Homeless Men Differentiated by Cocaine Use and Psychiatric Distress," Addictive Behaviors, 22, no. 2 (1997): 287-92; A.H. Kral et al., "Prevalence of Sexual Risk Behavior and Substance Use Among Runaway and Homeless Adolescents in San Francisco, Denver and New York City," International Journal of STD \& AIDS, 8 (1997): 109-17.

57. P. Bourgois, "The Moral Economies of Homeless Heroin Addicts: Confronting Ethnography, HIV Risk, and Everyday Violence in San Francisco Shooting Encampments, "Substance Use of Misuse, 33, no. 11 (1998): 2323-51.

58. Attorney General William Barr has been quoted as asserting that African-Americans would benefit disproportionately from increased incarcerations (of African-Americans) for drug offenses; M. Tonry, Malign Neglect: Race, Crime, and Punishment in America (New York: Oxford University Press, 1995): at 36. But see Drug Czar Barry McCaffery's description of our current incarceration policy: "We must have law enforcement authorities address the [drug use] issue because if we do not, prevention, education, and treatment messages will not work very well. But having said that, I also believe that we have created an American gulag." Gen. Barry R. McCaffrey (USA Ret.), Director, Office of National Drug Control Policy, Keynote Address, Opening Plenary Session, National Conference on Drug Abuse Prevention Research, National Institute of Drug Abuse, Washington, D.C., September 19, 1996, available at <http://165.112.78.61/ MeetSum/CODA/Keynote2.html >.

59. T.L. Meares, "Social Organization and Drug Law Enforcement, American Criminal Law Review, 35 (1998): 191-227, at $191,198-205$.

60. F.E. Zimring and G.J. Hawkins, Deterrence: The Legal Threat in Crime Control (Chicago: University of Chicago Press, 1973); G. Becker, "Crime and Punishment: An Economic Approach," Joumal of Political Economy, 76 (1968): 169-217.

61. T. Tyler, Why People Obey the Law (New Haven: Yale University Press, 1990); T.R. Tyler, "Public Trust and Confidence in Legal Authorities: What Do Majority and Minority Group Members Want from the Law and Legal Institutions?," Behavioral Sciences $\mathcal{G}$ the Law, 19 (2001): 215-35.

62. See Meares, supra note 59, at 212.

63. See id. at 210-14.

64. See Tyler, supra note 61.

65. See Meares, supra note 59.

66. S.F. Morin, "Early Detection of HIV: Assessing the Legislative Context," Joumal of Acquired Immune Deficiency Syndromes, 2, suppl. 2 (2000): S144-50.

67. Z. Lazzarini, S. Bray, and S Burris, "Evaluating the Impact of Criminal Laws on HIV Risk Behavior," Journal of Law, Medi- 
cine of Ethics, 30, no. 2 (2002): 239-53.

68. For discussions in the legal literature, see J.G. Hodge and L.O. Gostin, "Handling Cases of Willful Exposure Through HIV Partner Counseling and Referral Services," Women's Rights Law Reporter, 23 (2001): 45-62; K. Sullivan and M. Field, "AIDS and the Coercive Power of the State," Harvard Civil Rights-Civil Liberties Law Review, 23 (1988): 139-97; C.M. Shriver, "State Approaches to Criminalizing the Exposure of HIV: Problems in Statutory Construction, Constitutionality and Implications," Northern Illinois University Law Review, 21 (2001): 319-53; J. Mosiello, "Why the Intentional Sexual Transmission of Human Immunodeficiency Virus (HIV) Should Be Criminalized Through the Use of Specific HIV Criminal Statutes,"New York Law School Joumal of Human Rights, 15 (1999): 595-624; D.L. Chambers, "Gay Men, AIDS, and the Code of the Condom," Harvard Civil Rights-Civil Liberties Law Review, 29 (1994): 353-85; D.H.J. Hermann, "Criminalizing Conduct Related to HIV Transmission," Saint Louis University Public Law Review, 9 (1990): 351-78; G.P. Schultz and C.A. Parmenter, "Medical Necessity, AIDS, and the Law," Saint Louis University Public Law Review, 9 (1990): $379-419$; L. Gostin, "The Politics of AIDS: Compulsory State Powers, Public Health, and Civil Liberties," Obio State Law Journal, 49 (1989): 1017-58; G. Schultz, "AIDS: Public Health and the Criminal Law," Saint Louis University Public Law Review, 7 (1988): 65-113; M.L. Closen et al., "Discussion: Criminalization of an Epidemic: HIV-AIDS and Criminal Exposure Laws," Arkansas Law Review, 46 (1994): 921-83; M. Markus, "A Treatment for the Disease: Criminal HIV Transmission/Exposure Laws," Nova Law Review, 23 (1999): 847-79.

69. Zita Lazzarini, Principle Investigator, "Influence of Criminal Law on HIV Sexual Risk Behavior," supported by CDC grant numbers RO6/CCR118660-01 and H400-898-2021.

70. See Centers for Disease Control and Prevention, "HIVRelated Knowledge and Stigma - United States, 2000," Morbidity and Mortality Weekly Reports, 49, no. 47 (2000): 1062-64.

71. See M. Chesney and A. Smith, "Critical Delays in HIV Testing and Care: The Potential Role of Stigma," American Behavioral Scientist, 42 (1999): 1162-74; G. Herek, "AIDS and Stigma," American Behavioral Scientist, 42 (1999): 1106-16.

72. See Lazzarini, Bray, and Burris, supra note 67.

73. See Centers for Disease Control and Prevention, "Cluster of HIV-Positive Young Women - New York. 1997-1998," Morbidity and Mortality Weekly Reports, 48, no. 20 (1999): 41316.

74. See J. Wypijewski, "The Secret Sharer," Harper's Magazine, 297, no. 1778 (July 1, 1998): at 35 , for consideration of local response to issues of sex, race, and denial around the HIV epidemic.

75. See Centers for Disease Control and Prevention, supra note 3; Karon et al., supra note 9; Centers for Disease Control and Prevention, supra note 2; Zierler and Krieger, supra note 19; K.G. Castro, "Distribution of Acquired Immunodeficiency Syndrome and Other Sexually Transmitted Diseases in Racial and Ethnic Populations, United States; Influences of Life-style and Socioeconomic Status," Annals of Epidemiology, 3 (1993): 18184.

76. See U.S. Department of Housing and Urban Development's website for these definitions, available at $<\mathrm{http}$ :/ /www.hud.gov>.

77. Department of Housing and Urban Development v. Rucker, No. 00-1770, 2002 U.S. LEXIS 2144 (U.S. March 26, 2002).

78. See I.D. Montoya et al., "Barriers to Social Services for HIV-Infected Urban Migrators," AIDS Education and Prevention, 10, no. 4 (1998): 366-79.

79. See Lee et al., supra note 55.
80. See Takahashi, supra note 55.

81. See R.W. Pfeifer and J. Oliver, "A Study of HIV Seroprevalence in a Group of Homeless Youth in Hollywood, California," Joumal of Adolescent Health, 20, no. 5 (1997): 339$42 ;$ K. Clements et al., "A Risk Profile of Street Youth in Northern California: Implications for Gender-Specific Human Immunodeficiency Virus Prevention," Journal of Adolescent Health, 20, no. 5 (1997): 343-53; M.C. Clatts et al., "Correlates and Distribution of HIV Risk Behaviors Among Homeless Youths in New York City: Implications for Prevention and Policy," Child Welfare League of America, LXXVII, no. 2 (1998): 195-207; S.L. Bailey, C.S. Camlin, and S.T. Ennett, "Substance Use and Risky Sexual Behavior Among Homeless and Runaway Youth," Journal of Adolescent Health, 23, no. 6 (1998): 378-88; Kral et al., supra note 56.

82. See A.M Somlai et al., "Patterns, Predictors, and Situational Contexts of HIV Risk Behaviors Among Homeless Men and Women," Social Work, 43, no. 1 (1998): 7-20.

83. See G.A.D. Smereck and E.M Hockman, "Prevalence of HIV Infection and HIV Risk Behaviors Associated with Living Place: On-the-Street Homeless Drug Users as a Special Target Population for Public Health Intervention," American Joumal of Drug and Alcohol Abuse, 24, no. 2 (1998): 299-319; Zanis et al., supra note 56.

84. See A.A. Aidala et al., Housing, Health of Wellness Study: Final Report (October 4, 2000); P.S. Arno et al., "The Impact of Housing Status on Health Care Utilization Among Persons with HIV Disease," Journal of Health Care for the Poor and Underserved, 7 , no. 1 (1996): 36-49.

85. The World Bank Group, United States Data Profile, at $<$ http://devdata.worldbank.org/external/CPPProfile.asp? SelectedCountry $=$ USA\&CCODE $=$ USA \&CNAME $=$ United + States \&PTYPE $=\mathrm{CP}>$ (last visited February 6, 2002) (With a gross domestic product (GDP) per capita of $\$ 34,000$ (2000), the United States consistently rates in among the highest standards of living in the world and among the highest per capita GDP). Only seven countries had higher per capita GDP than the United States in 1999. These countries were Bermuda, Denmark, Japan, Liechtenstein, Luxembourg, Norway, and Switzerland. United Nations Statistics Division - Social Indicators, Indicators on Income and Economic Activity, at <http://www.un.org/Depts/unsd/ social/inc-eco.htm > (last visited February 7, 2002).

86. See A.B. Atkinson, L. Rainwater, and T.M. Smeeding, Income Distribution in OECD Countries: Evidence from the Luxembourg Income Study (Paris: Organisation for Economic Co-operation and Development, 1995) (the United States is one of the richest countries, and one with the most unequal distribution of income and wealth).

87. See U.S. Census Bureau, Income Inequality (March Current Population Survey) (Washington, D.C.: Government Printing Office, 1997) (inequality of income distribution in the United States is getting worse); E. Wolff, Top Heavy: A Study of the Increasing Inequality of Wealth in America (New York: 20th Century Fund, 1995).

88. I. Kawachi, "Income Inequality and Health," in L. Berkman and I. Kawachi, eds., Social Epidemiology (New York: Oxford University Press, 2000): 76-94; B.P. Kennedy, I. Kawachi, and D. Prothrow-Stith, "Income Distribution and Morality: CrossSectional Ecological Study of the Robin Hood Index in the United States," BMJ, 312 (1996): 1004-07 (see also important correction, BMJ, 312 (1996): 1194) (Analyzed age-adjusted death rates and income inequality in all fifty U.S. states, finding a strong correlation between greater degrees of income inequality and elevated death rates. Together, income inequality and poverty accounted for 25 percent of differences between state mortality 
rates, and over half of differences in homicide rates); J.W. Lynch et al., "Income Inequality and Mortality in Metropolitan Areas of the United States," American Joumal of Public Health, 88 (1998): 1074-80 (cities with low per capita income and high inequality had excess deaths of nearly 150 per 100,000 when compared to cities with relatively higher income and lower inequality).

89. M. Jacoby, "Does Indebtedness Influence Health? A Preliminary Inquiry," Journal of Law, Medicine \& Ethics, 30, no. 4 (2002): 560-71.

90. See Centers for Disease Control and Prevention, supra note 3 .

91. Burris, Kawachi, and Sarat, supra note 1.

92. See J.S. Lehman, "To Conceptualize, to Criticize, to Defend," Yale Law Journal, 101 (1991): 685-727 (public support for Aid to Families with Dependent Children decreased as concern grew that the program perpetuated dependence); T.R. Marmor, J.L. Mashaw, and P.L. Harvey, America's Misunderstood Welfare State: Persistent Myths, Enduring Realities (New York: Basic Books, 1990); H. Heclo, "Poverty Politics," in S.H. Danziger, G.D. Sandefur, and D.H. Weinberg, eds., Confronting Poverty: Prescriptions for Change (New York: Russell Sage Foundation, 1994): $396-437$.

93. See Personal Responsibility and Work Opportunity Reconciliation Act of 1996, Pub. L. No. 104-193 (August 1996) (Congress eliminated Aid to Families with Dependent Children and adopted The Personal Responsibility and Work Opportunity Reconciliation Act, which put a S-year lifetime limit on benefits, food stamps included).

94. U.S. Department of Health and Human Services, Indicators of Welfare Dependence, 2002 annual report to Congress: at Chapter II, "Indicators of Dependence," Figure IND3a, available at <http://aspe.hhs.gov/hsp/indicators02/index.htm>.

95. See J.S. Heymann, "Health and Social Policy," in L. Berkman and I. Kawachi, eds., Social Epidemiology (New York: Oxford University Press, 2000).

96. N. Zill, G. Resnick, and R.H. McKey, What Children Know and Can Do at the End of Head Start and What It Tells Us About the Program's Performance, paper presented at Emerging Views of Children in Poverty: The Health Start Family and Child Experiences Survey (FACES), the Society for Research in Child Development Biennial Meeting, Albuquerque, New Mexico, April 16, 1999, available at <http://www.2acf.hdhhs.gov/programs/hsb/hsreac/ faces/albqfinl2.doc $>$ (finding that children in Head Start achieve significant gains in preparedness for kindergarten and improvement in academically and socially related skills); E. Graces, D. Thomas, and J. Currie, Longer Term Effects of Head Start, DRU2439-NICHD/NSF, Labor and Population Program, Working Paper Series 00-20 (December 2000), available at <http:// www.rand.org/labor/DRU/DRU2439.pdf > (showing higher rate of high school graduation among Head Start participants).

97. See G. Burtless, "Public Spending on the Poor: Historical Trends and Economic Limits," in S.H. Danziger, G.D. Sandefur, and D.H. Weinberg, eds., Confronting Poverty: Prescriptions for Change (New York: Russell Sage Foundation, 1994) (Comprehensive Employment and Training Act (CETA) of 1973 benefited poor through job training, with 25-75 percent gains in wages of adult women who were trained).

98. Section 115 (a) of the Personal Responsibility and Work Opportunity Reconciliation Act of 1996, Pub. L. No. 104-193.

99. P. Allard, Life Sentences: Denying Welfare Benefits to Women Convicted of Drug Offenses (Washington, D.C.: The Sentencing Project, February 2002).

100. See id.

101. See B.M.J. Rotheram, "Expanding the Range of Interventions to Reduce HIV Among Adolescents," AIDS, 14, suppl. 1
(2000): S33-40.

102. See D. Cohen et al., "Broken Windows and the Risk of Gonorrhea," American Joumal of Public Health, 90, no. 2 (2000): 230-36.

103. See B. Lichtenstein, "Secret Encounters: Black Men, Bisexuality, and AIDS in Alabama," Medical Anthropology Quarterly, 14, no. 3 (2000): 374-93.

104. See J.L. Peterson, "AIDS-Related Risks and Same-Sex Behaviors Among African American Men," in M.P. Levine, P.M. Nardi, and J.H. Gagnon, eds., Changing Times: Gay Men and Lesbians Encounter HIVIAIDS (Chicago: University of Chicago Press, 1997): 283-301; Lichtenstein, supra note 103.

105. See L.A. Valleroy et al., "HIV Prevalence and Associated Risks in Young Men Who Have Sex with Men,"JAMA, 284, no. 2 (2000): 198-204.

106. Centers for Disease Control and Prevention, "HIV Incidence Among Young Men Who Have Sex with Men - Seven U.S. Cities, 1994-2000," Morbidity and Mortality Weekly Reports, 50 , no. 21 (2001): 440-44.

107. See Meares, supra note 59, at 213; D. James, "The Racial Ghetto as a Race-Making Situation," Law \& Society Inquiry, 19 (1994): 407, 420-28; E. Anderson, Streetwise: Race, Class and Change in an Urban Community (Chicago: University of Chicago Press, 1990): at 208.

108. See C. Shaw and H. McKay, Juvenile Delinquency and Urban Areas (Chicago: University of Chicago Press, 1969): at 321.

109. J. Fellner and M. Mauer, Losing the Vote: The Impact of Felony Disenfranchisement Laws in the United States (Washington, D.C.: Human Rights Watch, The Sentencing Project, 1998): at 8 (In 1998, approximately 1.4 million black men were disenfranchised, compared to a total of 4.6 million black men who voted in 1996. U.S. Census Bureau, Voting and Registration in the Election of November 1996 (July 1998): at 20-504).

110. See Meares, supra note 59. See generally S. Verba et al., Voice and Equality: Civic Voluntarism in American Politics (Cambridge: Harvard University Press, 1996).

111. See Meares, supra note 59, at 209-10.

112. L.A. Greenfield and T.L. Snell, Bureau of Justice Statistics, Women Offenders (Washington, D.C.: U.S. Department of Justice, 1999): at 8, Table 18.

113. C. J. Mumola, Bureau of Justice Statistics, Incarcerated Parents and Their Children (Washington, D.C.: U.S. Department of Justice, 2000): at 5 .

114. See Meares, supra note 59, at 207.

115. M. Mauer, Intended and Unintended Consequences: State Racial Disparities in Imprisonment (Washington, D.C.: The Sentencing Project, 1997): at 1 ("research has documented that a first-time arrest for a property crimes results in a $7 \%$ decline in incomes.").

116. See Meares, supra note 59, at 209-10.

117. S. Sekaran, New Policy with a Familiar Consequence: African Americans and the Higher Education Act, Drug Policy Alliance (February 27, 2002), available at <http://www.alternet.org/ story.html?'StoryID $=12501>$ (Higher Education Act (HEA) of 1998 delays or prohibits granting federal financial aid to any student convicted of nonviolent drug offenses, including misdemeanors.).

118. J. Dalaker, "Current Population Reports," Poverty in the United States: 2000 (Washington, D.C.: U.S. Government Printing Office, September 2001): at Table A; R. Blank, It Takes a Nation: A New Agenda for Fighting Poverty (Princeton: Princeton University Press, 1997); C. Jenks, Rethinking Social Policy: Race, Poverty, and the Underclass (New York: Harper Perennial, 1993).

119. See Meares, supra note 59, at 207. 
120. C. Haney and P. Zimbardo, "The Past and Future of U.S. Prison Policy. Twenty-Five Years After the Stanford Prison Experiment," American Psychologist, 53, no. 7 (1998): 709-27, at 716.

121. See Allard, supra note 99.

122. L.O. Gostin, S. Burris, and Z. Lazzarini, "The Law and the Public's Health: A Study of Infectious Disease Law in the United States," Columbia Law Review, 59 (1999): 99-128.

123. L.O. Gostin and J.M. Mann, "Towards the Development of a Human Rights Impact Assessment for the Formulation and Evaluation of Public Health Policies," Health and Human Rights, 1, no. 1 (1994): 58-80; L.O. Gostin and Z. Lazzarini, Human Rights and Public Health in the AIDS Pandemic (New York: Oxford University Press, 1997): at 57-67.

124. H. Watchirs, "Review of Methodologies Measuring Human Rights Implementation," Journal of Law, Medicine of Ethics, 30, no. 4 (2002): 716-33; E. O'Keefe and A. Scott-Samuel, "Human Rights and Wrongs: Could Health Impact Assessment Help?," Journal of Law, Medicine \& Ethics, 30, no. 4 (2002): 734-38.
125. D.P. Goldman et al., "The Impact of State Policy on the Costs of HIV Infection," Medical Care Research and Review, 58, no. 1 (2001): 31-53, 54-59 (discussion).

126. See Meares, supra note 59, at 217-20.

127. See id. at 219-20.

128. K. Strader, "Criminalization as a Response to a Public Health Crisis," Jobn Marshall Law Review, 27 (1994): 435-47, at 437.

129. See Lazzarini, Bray, and Burris, supra note $67^{\circ}$

130. R. Klitzman et al., "Views of HIV-Related Policies Among HIV Positive Men and Women: HIV Named Reporting, Partner Notification, and Criminalization of Non-disclosure" (2002, in review).

131. See Tyler, supra note 61.

132. P.M. Rowe, "Commentary: Changing the Risk Behavior of Politicians," Lancet, 349, no. 9051 (1997): 520.

133. H. Dalton, "Law and Responsibility Lecture Series: Shaping Responsible Behavior: Lessons from the AIDS Front," Washington oLee Law Review, 56 (1999): 931-52, at 934. 